\title{
Role of Women Politician in Political Contestation in Sikka (Phenomenological Study of Participation in Women Legislative Candidates)
}

\author{
Aseldi Lio ${ }^{1}$, Wike ${ }^{2}$ \\ \{seldy_dewa@yahoo.com ${ }^{1}$ \} \\ Universitas Brawijaya, Indonesia ${ }^{1,2}$
}

\begin{abstract}
The representation system as a modern form of democracy implies the opening of equal access and opportunities for citizens in politics. But political reality shows that women occupy a small part of political positions. This is because women's opinions that politics is dirty. A patriarchal culture that develops in society and places women in a lower position participates in perpetuating this. This study aims to: 1) Understand and analyze the meaning of female candidates in the role of women politicians, 2) To explain the meaning and experience of women legislative candidates in political contestation, 3). illustrate the meaning of the existence of female candidates as women politicians in political competition the method used is a qualitative method with a phenomenological approach and a liberal feminist perspective with participants of women politicians from several political parties. Research conducted in Sikka District shows that the meaning of the role of women politicians in political competition for each politician is different. The struggle for gender equality in politics has several limitations: 1) Not all women legislative candidates understand the gender agenda, 2) Women politicians who understand and fight for the gender agenda have not been elected as legislators, 3) Women politicians who understand the gender agenda and are chosen as legislators, do not optimal for managing gender issues because there are still cultural constraints related to patriarchy and its domestic role. Not all women politicians fight for gender issues. The meaning of the role of each woman politician is different.
\end{abstract}

Keywords: Phenomenology, Feminism, Meaning, Role, Female Politicians.

\section{Introduction}

The system of representation as a modern form of democracy implies the opening of equal access and opportunities for citizens in political activities [1]. Political reality shows that in most political systems, women occupy a small proportion in political positions and generally have relatively few positions of power and influence in public life compared to men [2][3][4].

Meanwhile patriarchal culture in society has placed women in a position that is always under men (subordinate), which causes vulnerability to the tendency of various stereotypes (negative labeling), marginalization (marginalization and impoverishment of women), subordination (which impacts on exploitation) and acts of violence [5]. This has the effect of making important decisions involving many people often considered too risky to be left to women. 
Women themselves according to Venny in Wijaksana [6], consider politics to be a dirty game. This assumption has hit the confidence of women in dealing with the political process. Self-mistrust is often the main cause of the absence of women in formal political stages such as in political parties, parliament or government. The disadvantage of these women in socioeconomic terms has put women into a group of citizens who are vulnerable to poverty, ignorance and underdevelopment and as a result woman have little chance to fight for their rights.

In Indonesia, the picture of the role of women in the public sector that is related to politics is still not encouraging. This can be observed from the election results from year to year still dominated by men as evidenced in the government with many male public officials, both in the executive, legislative and judicial regions. In politics women are often seen as not entitled to be leaders so that women are not interested in politics and are not aware of the discrimination of their rights and roles.

According to Bourdieau [7], basically the injustice that is often questioned by women is the crisis of women's presence in the public sphere due to their lack of accessibility to be involved. Women cannot express their existence and aspirations to be heard and carried out for the sake of gender equality. But the reality of the public domain as vital and strategic access to the flow of aspirations in society has a very patriarchal and masculine style. Public space is the only space that can create a rule that is fair and equal to women in society [8]. However, because the social structure that was formed actually resulted in women being marginalized from the means to voice their interests to be able to play an equal role in society.

Parliament or legislative body is a very strategic public space for a country, because this is where all policies are made and determined regarding the community. Women's presence in parliament is a vital indicator for a country that applies democratic principles in its government. The need for the role of women in politics and their involvement in parliament can ultimately determine that women can be treated fairly and equally.

In general, the world of politics is a world full of intrigue. The stage is full of fighting forces, the means of people to show off, where people struggle to gain, maintain and expand influence. Politics is the struggle for the meaning of "general truth". Things that are considered as general truths are finally decided as a policy or political decision. What is considered by decision makers as the final truth must be recognized as a shared truth. Even though political decisions are determined by a handful of people who are generally men, come from certain classes and are educated.

This makes the challenge of female politicians more severe than the struggle of male politicians, but all that must be done by women and therefore setting a $30 \%$ quota of women in parliament becomes very important in the context of affirmative action (temporary special actions) while providing opportunities as wide as broad for women to take part in politics.

Another base of thought is the belief that it is very important for women to increase their political participation both quantitatively and qualitatively, because by advancing into the public sphere and occupying strategic places of decision making as the only way for their interests to be represented [9]. These interests must be fought for by women themselves because it is impossible for men to formulate well.

From the number of legislative candidates even elected female legislative members have shown that women have not been able to emulate men in terms of political representation in the legislature. One reason is because of the dilemma experienced by women between selfmeaning, family and social life. The activities of legislators who demand a lot of time in the public sphere, meeting many different kinds of people with all their interests and the large amount of time that must be spent in public spaces become their own challenges for women. 
Its totality will be different from that of men because women are also required not to abandon domestic affairs.

This same phenomenon occurs in almost all of Indonesia, including in Sikka-NTT. The Sikka community is a patrilineal society. Differences in roles between men and women are done from birth. In the Sikka community, girls are considered outsiders and boys are considered insiders. This differentiation from birth will have an impact on the differentiation of treatment, rights and opportunities between men and women until he dies. Boys get more opportunities to develop themselves through education, politics and social life. Whereas women are very restricted subordinates to access and develop themselves so that fewer women become leaders or are involved in politics. Leading business and political affairs are men's business. Therefore, it is necessary to explore how a female legislative candidate interpreted her role as a female politician when entering politics participating in political contestation especially in Sikka.

\section{Research Methods}

This research uses social phenomenology which will explore lived body, lived time, lived space and lived relationship for 7 participants as female politicians with inclusion criteria. Women legislative candidates who temporarily occupy positions as members of Sikka Regency 2004-2019, candidates for women legislative failed in the legislative elections of the Sikka Regency DPRD for the period 2004-2019 and women legislative candidates who would take part in political contestation in the legislative elections of Sikka Regency DPRD period 2019-2024. This research was conducted in Sikka-NTT District and analyzed by Interpretative Phenomenological Analysis (IPA).

\section{Research Results and Discussion}

After in-depth interviews and data analysis, several themes were obtained that answered the questions in this study. The following themes obtained from the results of the analysis are as follows:

\subsection{The Meaning of the Prospective Women's Legislative Understanding of the Role of Female Politicians}

Understanding of the role of female politicians from each participant is different. There are participants who understand that the most important role of female politicians is to fight for a gender agenda with programs and activities as well as a budget for empowering women and children, able to channel women's aspirations to fulfill the needs and interests of women and children on the women's development agenda. To channel women's aspirations is needed power and for that women need political vehicles by joining as members in existing political parties.

In addition, the participants also interpreted the role of female politicians as regulators in developing gender responsive regulations. Gender issues or agendas need to be formulated in a policy regulation for women and children. Although the temporary political process is undertaken by the participants as candidates for the legislature has not arrived at the level of 
action to become a regulator, but participants have projected themselves to become a regulator so that the meaning can be explored.

Participants also understand that in order to become a female politician, they realize that it is not enough just to fight for the interests of women and children, but also to fight for the people's aspirations in general in fulfilling the basic rights of the community remains a priority.

\subsection{Motivation to become a legislative candidate in political contestation}

There is a difference in motivation among participants as female politicians. There are participants who have the motivation to fight for ideological gender. Participants felt called to overcome inequality and problems that occurred in the community especially the problems of women and children. Participants want to fight for programs/activities, the right budget to meet the needs of women and children. Participants feel that when they get the opportunity to become members of the legislature there will be many things that can be done for mothers and children. Participants have the motivation to fight for gender-sensitive programs, namely programs and activities that avoid discrimination against certain gender.

Furthermore, according to the research findings, there were participants who did not specifically have the motivation to fight for ideological gender when participating in becoming female politicians. This motivates them for professional reasons, namely experience in organizing, both experience in organizations that move on the issue of women and children and experience in their main tasks and functions in an organization that is in direct contact with the interests of women and children. Opportunities obtained due to position or husband's position in politics, as well as getting a husband's encouragement and also support from parents and family are one of the personal motivations for female politicians to enter politics.

\subsection{Experience Candidates for female legislators participate in political contestation}

The experience in question is the experience of participants during socializing themselves or during the campaign period. Based on the description of the themes above, it is known that each participant has a different experience from one another. It was found that in terms of the campaign material presented there were differences. There were participants who during the campaign period always presented gender issues as "political sales". Participants remain consistent to convey the main purpose of plunging into political contestation is to fight for gender equality by focusing more on the needs of women and also children.

While on the other hand there were participants who did not specifically address gender issues as material in socializing themselves. Participants convey programs that touch the community in general, namely the fulfillment of basic rights of the people, because according to them when basic rights have been fulfilled, then all programs and activities for gender equality will naturally be implemented.

Furthermore, there were participants who during the campaign period encountered obstacles. This obstacle is in the form of low self-confidence that is owned by the participant due to the dependence on the husband's presence during the campaign. Participants were not confident when they learned that her husband was not in the place where he was socializing himself. According to him this happened because as a housewife who was always accompanied by anywhere, she became less confident when she had to be released alone during the campaign. 
Other participants get their own challenges, namely getting obstacles from the women themselves jealousy between women. When getting an invitation to come to socialization to groups, the female politicians actually got obstacles from fellow women who showed a less friendly attitude compared to men.

\section{Conclusion}

It means that the role of women politicians in political contestation is to become champions in the gender agenda and channel people's aspirations. It was found that the struggle for gender equality in politics faced several obstacles, the first was that not all legislative candidates as women politicians understood the agenda on gender, secondly, when female politicians understood the agenda on gender but were not elected and the third after understanding the gender agenda and being chosen as legislators, women politicians do not optimally manage gender issues because there are still cultural constraints related to patriarchy and their domestic roles.

Therefore, fighting for an agenda on gender issues is more severe than fighting for other issues. As a result, when talking about budget allocations for regional apparatus organizations that have the task and function to empower women and children, the budget allocation is very small, because those who fight for it are also small.

\section{References}

[1] H. F. Pitkin, "Representation and democracy: uneasy alliance," Scan. Polit. Stud., vol. 27, no. 3, pp. 335-342, 2004.

[2] D. Dahlerup* and L. Freidenvall*, "Quotas as a 'fast track'to equal representation for women: Why Scandinavia is no longer the model," Int. Fem. J. Polit., vol. 7, no. 1, pp. 26-48, 2005.

[3] A. M. A. El Kharouf and M. Al-Jribia, "The Evolution of Women's Political Participation in Various Public Offices in Jordan," 2017.

[4] K. Marijan, Sistem politik Indonesia: konsolidasi demokrasi pasca Orde Baru. Kencana, 2019.

[5] A. Nurcahyo, "Relevansi Budaya Patriarki Dengan Partisipasi Politik dan Keterwakilan Perempuan di Parlemen," Agastya J. Sej. dan Pembelajarannya, vol. 6, no. 01, pp. 25-34, 2016.

[6] M. B. Wijaksana, "Perempuan dan Politik: Ketika yang Personal adalah Konstitusional," $J$. Peremp., vol. 34, 2004.

[7] P. Bourdieu, Dominasi Maskulin. Jakarta: Jalasutra, 2010.

[8] M. Fakih, “Analisis Gender \& Transformasi Sosial," Yogyakarta: Pustaka Pelajar, 2005.

[9] S. Marwah, "Reading Women Participations on Populism Politics," Polit. Indones. Indones. Polit. Sci. Rev., vol. 4, no. 2, pp. 255-273, 2019. 